\title{
Status Quo Unacceptable; Senate Reform Possible; Abolition by Stealth Anti-Democratic ${ }^{1}$
}

\author{
Linda Trimble*
}

\section{Introduction}

Given the media reaction to the Supreme Court's opinion in the Senate reference case, no one could fault Canadians for thinking the sky had suddenly fallen on Senate reform. "Did the Supreme Court just kill Senate reform?" asked a columnist for Maclean's magazine, and his answer was an unequivocal "yes." He declared, "that terrible screeching noise you heard this morning was the wheels of Senate reform in Canada grinding to a halt." Another news headline shouted, "Supreme Court ensures our widely reviled patronage house will stay forever." 3 The author of that particular article believes the practical effect of the Court's opinion "is to make Senate reform impossible."

The federal government clearly agrees. "Stuck with the status quo on Senate, says Harper after Court's rejection" read one newspaper headline. ${ }^{4}$ Immediately following the Court's ruling, the Prime Minister announced that the Government of Canada would not continue its work on Senate reform. This approach may be politically expedient for the Conservative government as it can publicly throw up its hands in defeat, blaming the Supreme Court for the lack of government action on parliamentary reform. But in my view, it's a politically irresponsible reaction, one that dismisses two easily-achieved and meaningful reform options. Plus, it precludes a substantive democratic discussion about the future of the Senate.
Also, importantly, it seems the Prime Minister has not actually given up on re-shaping the Senate. Mr. Harper is undertaking a covert demolition of the Upper House by refusing to appoint senators. I call this abolition by stealth. Because the government has been told it cannot unilaterally achieve its vision for Senate reform, it is opting to disassemble the Senate and is refusing to consult with Canadians and their provincial governments about substantive and achievable reforms.

I will begin by challenging the federal government's assertion that the Supreme Court decision effectively makes meaningful Senate reform impossible. Then, I will discuss the move towards abolition and explain why I think it's both reckless and anti-democratic. Finally, I'll conclude by making a pitch for a truly deliberative process a national conversation on the future of the Senate in the form of a citizen's assembly.

\section{Reform is possible, and desirable}

Officially, the Government of Canada has shut the door on Senate reform. But, giving up on reform ignores a couple of obvious modifications that could be enacted quickly, and quite easily. The first is removing the property requirement for Senate appointees, and the second is changing the mechanism for selecting senators. In my view, these two initiatives could dramatically alter the make-up of the Senate. 


\section{Property requirement}

Let's start with the property qualification. That the Constitution Act, 1867 requires every senator to own land worth at least $\$ 4,000$ dollars, plus real and personal property worth at least $\$ 4,000$ dollars, above debts and liabilities, effectively rules out a lot of people. In the Senate reference, the Supreme Court was asked whether or not the federal government could unilaterally remove the property requirement. That the Court said "yes" was read as throwing the Harper government a bone, but I think it's much more significant than that. Removing the property qualification is a potentially meaningful constitutional amendment, one that could make a difference to the composition of the Senate. After all, it was clearly designed to build an upper house that represents the propertied elite. As political scientist David Docherty writes, "It is clear that the intention of the framers of the Senate was to use the property qualification as part of the method of making the upper chamber a more elitist and conservative body than the lower house." ${ }^{5}$ The Senate continues to reflect this outdated perspective as senators overwhelmingly represent the interests of the corporate class. Indeed, some senators own and run businesses. For instance, a recently retired senator owned two major sports teams, the Toronto Argonauts and the BC Lions, ${ }^{6}$ and many others serve as directors or board members of major corporations. In fact, one of the senators at the heart of the expenses scandal, Pamela Wallin, allegedly claimed travel costs for performing exactly these sorts of corporate duties.

Arguably, the interests of the middle or working classes could be much more effectively voiced in the Senate if the property requirement was lifted. It is a simple matter of the federal government passing a piece of legislation to remove the property qualification for senators. The province of Quebec would have to agree to this change for its Senate appointees, who are required by the Constitution Act to hold property in Quebec. But, there's no evidence that the Quebec government would oppose such a move, and the province might in fact welcome the chance to update an arcane provision of the Constitution. ${ }^{7}$ After all, no one would lose. The Prime Minister could still appoint people from the propertied elite, and Canadians would arguably gain a great deal if a much wider range of people were qualified for appointment to the Senate. This initiative would boost representation from groups that tend to have fewer economic resources, such as women, racialized minorities, and indigenous Canadians.

\section{Appointments process}

The second reform is even easier to accomplish because the decision can be simply and straightforwardly taken at the prime minister's discretion. The PM can immediately change the appointment process. Even some Conservatives think this is a good idea. The Conservative Party's former campaign manager, Tom Flanagan, urged the government to develop a Plan B for Senate reform in the likely eventuality that the Supreme Court ruling did not go the government's way. ${ }^{8}$

Flanagan suggested that provincial advisory committees get the job of recommending names for the consideration of the prime minister. Peter Russell, Canada's preeminent constitutional and parliamentary scholar, has an even bolder suggestion: "What if the prime minister was brave and principled enough to publicly commit himself to ending patronage to the Senate and agree to be advised on Senate appointments by a nonpartisan council of Canadians representing all fields of endeavor?" 9

Last January, the leader of the Liberal party, Justin Trudeau, announced that this is the sort of action he would take if his party formed the government. Trudeau recommends a non-partisan appointment process that would fill the Senate with independents. To show the strength of his intentions, Mr. Trudeau announced that Liberal senators were ejected from the Liberal parliamentary caucus effective immediately. ${ }^{10}$ The reaction from pundits was mixed. One columnist called “Trudeau's Senate idea fresh, brave - and worth considering." 11 Another judged the proposal "a breathtaking confusion of stupidities" because, of course, the Liberal senators continue to maintain their partisan allegiances. ${ }^{12}$ Will Mr. Trudeau actually implement this policy if elected? We will see; a Trudeau government 
would confront a Senate full of Conservative appointees, and the temptation to restack the deck with Liberals may prove irresistible.

In response to the Liberal Party's position, the Prime Minister said changing the appointments process is merely cosmetic and will do nothing to make the Senate more democratic and accountable. To quote Mr. Harper: "Canadians are not looking for a better unelected Senate. Canadians believe that for the Senate to be meaningful in the $21^{\text {st }}$ Century, it must be elected." ${ }^{13}$ But without any immediate prospects for an elected Senate, maybe Canadians would indeed prefer a better, more representative, less partisan unelected Senate. And, if the Prime Minister is so determined that the Senate be elected, why hasn't his government pursued this option in a manner respectful of the constitution? Why didn't he immediately initiate discussions with the provinces about constitutional reform?

As the Supreme Court's opinion confirms (and as everyone already knew) a constitutional amendment is necessary to achieve an elected Senate. Here's the prime minister's explanation for refusing to even try: "We know that there is no consensus among the provinces on reform, no consensus on abolition, and no desire of anyone to reopen the Constitution and have a bunch of constitutional negotiations." ${ }^{14}$ He's right about the fact that there's no agreement on how to fix the Senate; there never has been. But does this mean we should simply give up on trying to reform the Upper House? Absolutely not.

Reform is possible, and Canadians desperately need a national conversation about the role of the Senate. As political scientist Emmett Macfarlane argues, "It is one thing to make the case that the current situation is unpalatable, it is another to answer the question, 'what should the Senate be for?"' 15 Of course Canadians are going to disagree about the answer to this question, and about whether or not we even need an Upper House. But saying we can't start the conversation because provincial governments won't be able to reach a consensus suggests Canadians should not have any say in the design of their national institutions.
Maybe politicians find comfort in this selfimposed constitutional straightjacket. It allows them to avoid risk and uncomfortable levels of scrutiny. In my view, Mr. Harper's assertion that there's no desire to reopen the constitutional dialogue is short-sighted. Maybe, in the wake of the Senate expenses scandal, now is the perfect time for a single-issue round of constitutional reform, focused exclusively on the Senate. Everyone is talking about it anyway, and the conversation heated up again when the Duffy trial began.

The fact that Canadians know so little about the functions of the Senate indicates that a conversation would play a highly useful educative role. A public opinion survey published last February found that very few Canadians can explain what senators do on a daily basis, nor can they identify the role of the Senate in the Canadian parliamentary system. ${ }^{16}$ So, even if nothing came of national deliberations on Senate reform, people would learn about the Senate's past and be encouraged to thoughtfully consider its possible futures.

I think we need a constitutional discussion, ideally in the wake of a citizen's assembly on the future of the Senate, but I certainly would not bet a great deal of money on the likelihood of a federal government starting constitutional talks in the near future, regardless of which party leads the government. Mr. Harper's belief that "there's no desire of anyone to reopen the Constitution" is a mantra among federal politicians of all partisan stripes. Political leaders utter this assertion with such synchronistic finality it is now accepted as capital " $T$ " truth. Yet, public opinion polls reveal increasing support for constitutional reform, in the province of Quebec and indeed across the country. ${ }^{17}$ For instance, a survey conducted a couple of years ago, well before the Senate scandal erupted, found 61 percent of Canadians are prepared to reopen the Constitution in an effort to reform or abolish the Senate. ${ }^{18}$ It seems many Canadians have now recovered from the posttraumatic stress disorder produced by previous rounds of constitutional negotiations. It's not so risky anymore to talk about the Constitution. The Quebec sovereignty movement is currently 
in abeyance, so there is a lessened risk of sparking a national unity crisis.

Another reason to hope for Senate reform via constitutional amendment is because younger people are much more likely than older citizens to prefer reforming the Senate to abolishing it. ${ }^{19}$ The students I teach, the future generations of policy-makers, are more positive about the prospects for fixing the Senate. However, constitutional reform won't happen under the watch of the present government, which has shut the door on any national deliberation about the future of the Senate, and is pursuing abolition by stealth.

\section{Abolition by stealth}

The federal government seems to be doing its best to quietly make the Senate disappear. The Prime Minister has stopped appointing senators. The last appointment was made in March 2013, and there are now 18 vacancies (not including the suspended senators). The prime minister says he is in no hurry to make appointments. In Mr. Harper's words: "We're able to continue to pass our legislation through the Senate, so from our standpoint the Senate of Canada is continuing to fulfill its functions." ${ }^{20}$ According to Emmett McFarlane, "killing the Senate by simple attrition of its membership is a tactic favoured by people who want the Upper House gone, but recognize, in large part due to last April's Supreme Court reference opinion, that Parliament can't institute major reform or abolition by itself." ${ }^{21}$ Indeed, former Conservative Senator Hugh Segal recently tipped the government's hand by saying he doesn't think the Prime Minister has any obligation to name senators as long as the Upper House meets its quorum of 15 members. ${ }^{22}$ Moreover, a major champion of abolition, Saskatchewan Premier Brad Wall, recently declared: "Atrophy is not a bad endgame for the Senate.... It's a long goodbye but it is a goodbye." 23 The New Democratic Party, which strongly supports abolition, also commends this approach. As leader Tom Mulcair put it, "We could just let the thing die on the vine - just wither away, name no one else to the Senate." 24

Getting rid of the Senate in this manner is clearly unconstitutional. Perhaps more impor- tantly, it's politically irresponsible. In my view, Canada needs an Upper House, not least because of the extreme concentration of power in the executive branch of the national government. The type of careful legislative oversight that the Senate is designed to provide is crucial given the fusion of powers. While many thoughtful people are in favour of abolition, and I certainly would like to have the opportunity to participate in a discussion about it, abolition by stealth seems designed to avoid talking about the future of the Senate. It is petulant and negligent of the current government to simply throw up its hands in the wake of the Supreme Court's decision and to resist any form of democratic dialogue on Senate reform.

\section{Conclusion}

In the throes of the Senate expenses scandal, the Premier of Saskatchewan tweeted: "Abolition difficult, reform impossible, status quo unacceptable." ${ }^{25}$ I agree with Mr. Wall on one point - the status quo is unacceptable. At the very least, the Prime Minister has a duty to address the problems that generated the expenses scandal, and to clean up the appointments process. My argument, in one sentence, is this: status quo unacceptable, abolition by stealth anti-democratic, meaningful reform possible and definitely worth pursuing. As Canadians wait in vain for politicians to agree on how to democratize the institution, maybe we do want a better, unelected Senate. The federal government can easily amend the Constitution to remove the property qualification for senators, and the Prime Minister can revamp the appointments process. I have argued that Canada desperately needs a national dialogue on the fate of the Senate, and on its roles and practices, should we decide to keep it. This conversation should itself be fully representative and deliberative, so I advocate the creation of a citizen's assembly on the role and fate of the Senate. I sincerely hope a future government will gather sufficient courage and, yes, boldness to engage Canadians in a conversation about this important national issue. 


\section{Notes}

* Linda Trimble, Professor, Department of Political Science, University of Alberta.

1 Portions of this paper were presented as a Senate Occasional Lecture in Canberra, Australia, and published in Papers on Parliament: Lectures in the Senate Occasional Lecture Series, and Other Papers, October 2014 at 131-146.

2 Emmett Macfarlane, "Did the Supreme Court just kill Senate reform?", Maclean's Magazine (24 April 2014).

3 Andrew Coyne, "Supreme Court ensures our widely reviled patronage house will stay forever", The National Post (25 April 2014).

4 Sean Fine, "Stuck with status quo' on Senate, says Harper after court's rejection", The Globe and Mail (25 April 2014).

5 David Docherty, "The Canadian Senate: chapter of sober reflection or loony cousin best not talked about" (2002) 8:3 Journal of Legislative Studies at 30 .

6 Joanna Smith, "Many Canadian Senators make money outside the Senate", National Newswatch (4 July 2013).

7 See Hon. Dan Hays, "Updating some antiquated constitutional provisions relating to the Senate" (2009) Spring Canadian Parliamentary Review, at 21-25.

8 Tom Flanagan, "House of Lords offers a Plan B for Senate reform", The Globe and Mail (27 May 2013).

$9<$ http://ontarionewswatch.com/onw-news. html?id=532>.

10 Gloria Galloway \& Josh Wingrove, "Trudeau cuts Liberal senators loose in push for a non-partisan Red Chamber", The Globe and Mail (29 January 2014).

11 Jeffrey Simpson, "Trudeau's Senate idea fresh, brave: and worth considering", The Globe and Mail (30 January 2014).

12 John Pepall, "Trudeau’s Senate plan: 'a breathtaking confusion of stupidities"', The Globe and Mail (30 January 2014).

13 Steven Chase, "Canadians want an elected Senate, Harper says after Trudeau boots senators", The Globe and Mail (29 January 2014).
14 Abbas Rana, 'Senate a 'colonial relic', should be abolished: former Tory MP Boyer", The Parliament Hill Times (23 June 2014), online: <http://www. hilltimes.com/news/news/2014/06/23/senate-acolonial-relic--should-be-abolished-former-torymp-boyer/38890>.

15 Emmett Macfarlane, "What do we really want to do with the Senate?", Maclean's Magazine (22 July 2013).

16 Dean Beeby, "Government polls Canadians about Senate scandal", The Globe and Mail (14 February 2014).

17 Philip Authier, "Majority of Quebecers want constitutional reform, poll finds", Montreal Gazette (26 March 2012).

18 Joan Bryden, "Most Canadians now willing to reopen Constitution, poll finds", The Globe and Mail (26 May 2011).

19 Angus Reid Global, "Should the Canadian Senate be abolished? 50\% surveyed say yes", (8 November 2013), online: <http://www.angusreidglobal.com/ wp-content/uploads/2013/11/Senate-ScandalNovember-2013.pdf $>$.

20 Canadian Press, "Harper says he is in no hurry to appoint more senators", The Globe and Mail (4 December 2014).

21 Emmett Macfarlane, "Why we can't just ignore the Senate and hope it goes away: The latest halfbaked plan for Senate reform", Maclean's (14 July 2014).

22 CBC News, "Brad Wall says Senate atrophy is not a bad end game", CBC.ca (12 July 2014) online: <http://www.cbc.ca/news/politics/bradwall-says-senate-atrophy-is-not-a-bad-endgame-1.2704203>.

23 Ibid.

24 Ibid.

25 Brad Wall, "Meaningful Senate reform means 'equal' prov rep. Populous provs won't agree. Abolition difficult, reform impossible, status quo unacceptable" (24 May 2013 at 3:39pm), online: <https://twitter.com/premierbradwall/ status/338061707710697472>. 
